\title{
The Effect of Losartan on Platelet Aggregation and Hematological Parameters in Patients with Newly Diagnosed Hypertension
}

\author{
Losartanın Yeni Tanı Hipertansiyon Hastalarının Hematolojik \\ Parametrelerine ve Trombosit Agregasyonuna Etkisi
}

\author{
Mustafa Ünübol1, İrfan Yavaşoğlu22, Bilal Acar³, Gürhan Kadıköylü2, Zahit Bolaman² \\ ${ }^{1}$ Adnan Menderes University Faculty of Medicine, Department of Internal Diseases, Science of Endocrinology and Metabolism Diseases, Aydın, Turkey \\ ${ }^{2}$ Adnan Menderes University Faculty of Medicine, Department of Internal Diseases, Science of Hematology, Aydın, Turkey \\ ${ }^{3}$ Çankırı State Hospital, Clinic of Internal Diseases, Çankırı, Turkey
}

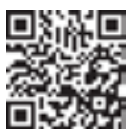

Keywords

Losartan, platelet aggregation, hemoglobin, hypertension

\section{Anahtar Kelimeler}

Losartan, trombosit agregasyon, hemoglobin, hipertansiyon

Received/Geliş Tarihi : 05.08.2015

Accepted/Kabul Tarihi : 12.11.2015

doi:10.4274/meandros.2438

Address for Correspondence/Yazışma Adresi: Mustafa Ünübol MD,

Adnan Menderes University Faculty of

Medicine, Department of Internal Diseases,

Science of Endocrinology and Metabolism

Diseases, Aydın, Turkey

Phone : +90 2564441256

E-mail :drmunubol@yahoo.com.tr

Presented by Congress: $12^{\text {th }}$ Congress of the European Hematology Association, June 7-10, is presented as a poster in 2007. Haematologica 2007; 92 [suppl.2]: 499. Abstract abstract book was published in 1390 .

(C) Meandros Medical And Dental Journal, published by Galenos Publishing.

(C) Meandros Medical And Dental Journal, Galenos Yayınevi tarafından basılmıştır.

\begin{abstract}
Objective: Hypertension is associated with increased platelet function. Some antihypertensive drugs have antiplatelet activity. In this study, we aimed to investigate the effects of losartan on platelet aggregation induced by adenosine diphosphate (ADP), collagen, epinephrine, ristocetin, other hematological and, inflammatory parameters.

Materials and Methods: Twenty-five patients (19 female, 6 male; mean age: $54 \pm 8$ years) with newly diagnosed hypertension were included in the study. All patients were with stage 1-2 essential hypertension according to the seventh report of the Joint National Committee on prevention, detection, evaluation, and treatment of high blood pressure. Initial blood pressure measurement was performed in all patients and losartan $100 \mathrm{mg} /$ daily together with life style changes, such as diet and exercise was started. Platelet aggregation was evaluated with the use of ristocetin, epinephrine, collagen, and ADP. Complete blood count was also done. Platelet aggregation tests and blood pressure measurements were repeated after 8 weeks of therapy.

Results: Systolic and diastolic blood pressure significantly decreased with losartan after 8 weeks $(p<0.001)$. After treatment, there was no significant difference in platelet aggregation with ADP, collagen, and epinephrine ( $p>0.05)$. The aggregation with ristocetin significantly decreased $(p=0.027)$. Besides, significantly lower hemoglobin and hematocrit levels were observed ( $p=0.034, p=0.039$, respectively). Conclusion: Losartan may produce independent activities apart from its antihypertensive effects by providing significant reductions in platelet aggregation with ristocetin, and in hematocrit levels with hemoglobin. Therefore, it may be beneficial in the prevention of atherosclerosis and thrombosis.
\end{abstract}

Öz

Amaç: Hipertansiyon artmış trombosit fonksiyonu ile ilişkilidir. Bazı antihipertansif ilaçların anti-trombosit aktiviteleri vardır. Biz bu çalışmada, losartanın adenozin difosfat (ADP), kollajen, epinefrin, ristosetin ile trombosit agregasyonuna, diğer hematolojik ve enflamatuvar parametreler üzerine etkilerinin araştırılmasını amaçladık. 
Gereç ve Yöntem: Çalışmaya yeni tanı hipertansiyonlu ortalama yaşı 54₫8 yıl olan 19'u kadın, 6'sı erkek 25 hasta alındı. Yüksek kan basıncını önleme, saptama, değerlendirme ve tedavi üzerine Birleşik Komite'nin yedinci raporuna göre tüm hastaların, evre 1-2 esansiyel hipertansiyon tanısı mevcuttu. Başlangıç kan basınçları ölçüldü ve her bir hastaya diyet, egzersiz gibi yaşam tarzı değişikliği ile birlikte losartan $100 \mathrm{mg} / g u ̈ n$ tedavisi başlandı. Tedavi öncesi ristosetin, epinefrin, kollagen ve ADP ile trombosit agregasyonu değerlendirildi. Ayrıca tam kan sayımları ölçüldü. Trombosit agregasyon testleri ve kan basıncı ölçümleri tedaviden 8 hafta sonra tekrar değerlendirildi.

Bulgular: Losartan ile 8 haftanın sonunda sistolik ve diyastolik kan basıncında anlamlı düşüş saptandı ( $p<0,001)$. Tedavi sonrası, ADP, kollajen ve epinefrin seviyeleri ile trombosit agregasyonunda anlamlı farklılı saptanmadı $(p>0,05)$. Ristosetin ile agregasyon önemli ölçüde azaldı $(p=0,027)$. Aynı zamanda, önemli ölçüde düşük hemoglobin ve hematokrit seviyeleri gözlemlendi ( $p=0,034$ ve 0,039 , sırasıyla).

Sonuç: Losartan, hemoglobin ile hematokrit seviyelerinde ve ristosetinle trombosit agregasyonunda önemli ölçüde düşüş sağlayarak antihipertansif etkisinden bağımsız aktiviteler ortaya koyabilir. Bu sayede aterosklerozun ve trombozun önlenmesinde faydalı olabilir.

\section{Introduction}

Hypertension is a multifactorial and heterogeneous disease that presents as high blood pressure. Uncontrolled hypertension can cause stroke, myocardial infarction, heart failure, chronic kidney disease, and premature death (1). Angiotensin receptor blockers (ARBs) are effective and safe drugs. Angiotensin II is the main active component of the renin-angiotensin system. In addition, angiotensin II is an etiological factor for hypertension. Angiotensin II type-1 (AT1) receptor stimulation has been shown to be associated with effect of angiotensin II $(2,3)$. Losartan is one of the orally active non-peptidic AT1 receptor antagonists (2).

ARBs are used for the treatment of heart failure and nephropathy. Besides, ARBs prevent new or recurrent stroke incidence in hypertensive patients. In addition, ARBs have been shown to possess antiatherogenic, antioxidant, antidiabetic, and antiplatelet aggregating effects. These beneficial effects show that ARBs have pleiotropic effects (3). In several studies, it has been shown that essential hypertension was associated with increased platelet aggregation (4). Some classes of antihypertensive drugs have also antiplatelet activity (5-7).

In this study, our aim was to investigate the effects of losartan on in-vitro induced platelet aggregation by adenosine diphosphate (ADP), collagen, epinephrine, ristocetin, erythrocyte sedimentation rate (ESR), and C-reactive protein (CRP) levels as well as platelet and white blood cell (WBC) counts.

\section{Materials and Methods}

This study included 25 patients ( 19 female, 6 male; mean age: $54 \pm 8$ years) with essential hypertension. All patients were with stage 1-2 essential hypertension according to the seventh report of the Joint National Committee on the prevention, detection, evaluation, and treatment of high blood pressure (8). Blood pressure measurements were performed after the subjects had rested in the supine position for at least 15 minutes in a quiet examining room, at the same room temperature, with the same sphygmomanometer. Three measurements were done at 2-minute intervals and the mean value was recorded. Exclusion criteria were: coronary artery disease, heart failure, secondary hypertension, an acute illness, obesity (body mass index $>35 \mathrm{~kg} / \mathrm{m}^{2}$ ), a previous diagnosis of thrombotic events, known hypercoagulable states, major surgery in the past 3 months, current exposure to anti-platelet therapy, non-steroidal anti-inflammatory drugs use, anti-hyperlipidemic therapy, antidepressant drugs or oral contraceptives use, smoking, diabetes mellitus, chronic renal failure, malignancy, and history of allergic reaction to losartan.

All patients underwent physical examination. Urinalysis, and laboratory tests (blood counts, renal function tests, electrolytes, lipid levels, CRP, ESR) were evaluated. After stopping drugs for 10 days, platelet aggregation tests with ADP, epinephrine, collagen, and ristocetin were performed. All patients underwent chest X-ray and 12-lead electrocardiogram. Biochemical analyses and CRP measurements were performed using an immuno-analyzer (Access Immunoassay System, Beckman-Coulter). Losartan, $100 \mathrm{mg} /$ daily together with life style changes, such as diet and exercise were started. The patients were asked to take their medication at 10:00 am. Platelet aggregation tests and blood pressure measurements were repeated 8 weeks after therapy. Informed consent was obtained from all participants.

Platelet aggregation (Chrono-log, 570 blood aggregation systems, Havertown, USA) was evaluated 
with the use of ristocetin, epinephrine, collagen, and ADP. Complete blood count (Beckman-Coulter) was also evaluated.

Twenty milliliter venous blood samples were anticoagulated with $1 \mathrm{ml}$ of $3.8 \%$ trisodium citrate. Aggregation test was performed within 30 minutes after sampling. Platelet-rich plasma (PRP) was prepared by centrifugation of the blood at $800 \mathrm{rpm}$ for 15 minutes at $20^{\circ} \mathrm{C}$. For each test, $450 \mu \mathrm{L}$ PRP were collected in glass tubes and were fitted up in PRP washbowl. The supernatant was drawn into another tube, and the remaining PRP again centrifuged at 4000 rpm for 10 minutes to obtain platelet-poor plasma (PPP). Four hundred-fifty $\mu \mathrm{L}$ PPP was put into PPP washbowl and incubated at $37^{\circ} \mathrm{C}$ for 2 minutes. Then it was stirred again for 2 minutes in the aggregometer. Changes in optical density were recorded for 6 minutes after the platelets were stimulated with ADP, epinephrine, collagen and ristocetin. ADP, epinephrine, and collagen were studied by $3 \mu \mathrm{L}$ and ristocetin was studied by $4 \mu \mathrm{L}$. A turbidity curve expressing the relationship between the amplitude and the rate of the aggregation was calculated for each patient's sample. The lowest light transmission at the end of the 6 minutes was recorded as the maximal aggregation percentage (\%). The time that $50 \%$ of maximal aggregation occurred was recorded as the aggregation rate (seconds) $(9,10)$.

\section{Statistical Analysis}

Statistical Package for Social Sciences version 16.0 was used for statistical analyses. A p value of less than 0.05 was considered statistically significant. All results were presented as mean \pm standard deviation. Fit of the quantitative data to normal distribution was studied using the Kolmogorov Smirnov test. Statistical analyses were performed using two-paired student's t-test.

\section{Results}

Parameters before and after treatment with losartan are shown in Table 1. Systolic and diastolic blood pressure significantly decreased with losartan after 8 weeks of treatment $(p<0.001)$. After treatment, there was no significant difference in platelet aggregation with ADP, collagen, and epinephrine $(p>0.05)$. After losartan treatment, platelet aggregation with ristocetin significantly decreased $(p=0.027)$. In addition, hemoglobin and hematocrit

\begin{tabular}{|c|c|c|c|}
\hline & $\begin{array}{l}\text { Before } \\
\text { treatment }\end{array}$ & $\begin{array}{l}\text { After } \\
\text { treatment }\end{array}$ & $\mathbf{p}^{*}$ \\
\hline $\begin{array}{l}\text { Systolic blood } \\
\text { pressure }(\mathrm{mmHg})\end{array}$ & $161 \pm 15$ & $122 \pm 9$ & $<0.001$ \\
\hline $\begin{array}{l}\text { Diastolic blood } \\
\text { pressure }(\mathrm{mmHg})\end{array}$ & $96 \pm 8$ & $80 \pm 2$ & $<0.001$ \\
\hline Ristocetin (\%) & $78 \pm 18$ & $64 \pm 22$ & 0.027 \\
\hline ADP (\%) & $82 \pm 18$ & $79 \pm 14$ & $>0.05$ \\
\hline Collagen (\%) & $93 \pm 14$ & $92 \pm 14$ & $>0.05$ \\
\hline Epinephrine (\%) & $70 \pm 21$ & $64 \pm 20$ & $>0.05$ \\
\hline Hemoglobin (g/dL) & $13.9 \pm 1.5$ & $13.3 \pm 1.2$ & 0.034 \\
\hline Hematocrit (\%) & $39.8 \pm 4.3$ & $38.5 \pm 3.3$ & 0.039 \\
\hline $\begin{array}{l}\text { White blood cell } \\
\text { counts }(\mu l) \times 10^{3}\end{array}$ & $6.7 \pm 1.3$ & $6.4 \pm 1.5$ & $>0.05$ \\
\hline $\begin{array}{l}\text { Platelet counts }(\mu \mathrm{l}) \\
\times 10^{3}\end{array}$ & $271.4 \pm 45.9$ & $267.6 \pm 70.4$ & $>0.05$ \\
\hline $\mathrm{ESR}(\mathrm{mm} / \mathrm{h})$ & $23 \pm 13$ & $24.6 \pm 12$ & $>0.05$ \\
\hline CRP (mg/L) & $1.6 \pm 2.9$ & $1.8 \pm 2.3$ & $>0.05$ \\
\hline
\end{tabular}

levels decreased significantly $(p=0.034, p=0.039$, respectively). However, there was no difference in ESR, CRP levels, platelet counts, and WBC counts $(p>0.05)$.

\section{Discussion}

In our study, we detected a significant decrease in hematocrit levels with hemoglobin and platelet aggregation with ristocetin in patients treated with losartan.

Atherosclerosis develops as a process occurring in the walls of arteries, which begins with a cellular and infiltrative response to an endothelial injury (11). Circulating activated platelets have been shown to be associated with an increased risk of thrombotic events. This condition is related to stroke, diabetes mellitus, and hyperlipidemia (12).

Activated platelets play an important role in the formation of acute coronary syndromes including platelets and endothelial cells, leukocytes, and erythrocytes. Angiotensin II as a vasoconstrictor could contribute to thrombotic process. Platelets express AT1 receptors on their surface $(13,14)$. Losartan is one of the non-peptidic AT1 receptor antagonists. In 
their study, Montón et al. (13) stimulated platelets with the thromboxane A2 (TXA2) analogue U46619. They have found that stimulated platelet activation by the TXA2 analogue U46619 was significantly reduced by losartan. Jimenez et al. (15) demonstrated that losartan decreased P-selectin expression in platelets obtained from stroke-prone spontaneously hypertensive rats. On the other hand, administration of losartan decreased the number of activated platelets independently of its antihypertensive effects.

In Japanese patients with mild-to-moderate hypertension (J-ELAN) study (16) losartan and amlodipine were compared and losartan was found to be efficient in preventing the progression of atherosclerosis of the carotid artery.

In a study by Chabielska et al., (17) acute and sub chronic ( 5 days) losartan administration did not change the aggregating response of normotensive rat platelets. Nossaman et al. (18) demonstrated that losartan significantly decreased arachidonic acidinduced platelet aggregation in a rat, but candesartan had no effect.

Sato et al. (2) showed the inhibition of platelet aggregation with ADP after losartan treatment. They used highly sensitive particle counting method using laser-light scattering. They stated that this effect could be independent of antihypertensive actions and the positive effects of losartan on decreasing cardiovascular events in hypertensive patients might be partly mediated by inhibition of platelet activation. Nomura et al. (19) found that CD62P, CD63, PAC-1 (a marker specific for activated glycoprotein IIb/IIla), platelets, endothelial microparticles, and soluble adhesion markers diminished with losartan in hypertensive patients with diabetes. They concluded that losartan together with simvastatin might prevent the development of cardiovascular events caused by platelets and microparticles in addition to reduction of blood pressure or lipid levels in hypertensive and hyperlipidemic patients with diabetes. On the contrary, Akdemir et al., (20) in their study investigating effects of losartan on platelet aggregation with ADP and ristocetin, found no significant differences.

Yamada et al. (21) showed that spontaneous platelet aggregation was not significantly reduced after losartan treatment whilst CD62P was significantly decreased $(p=0.016)$. These results suggested that losartan shows antiplatelet effect as measured by CD62P levels.
The LIFE study suggested that beneficial effect of losartan on stroke may result from a mosaic of mechanisms such as thrombus formation/ platelet aggregation rather than a single action (22). Losartan passivates ex vivo platelet activation, probably by means of blockade of TXA2 receptordependent signaling (23). It has been shown that losartan significantly reduced megakaryocyte ploidy, megakaryocyte size, and lengthened cutaneous bleeding time, in hypertensive patients $(4,24)$. Losartan reduced platelet aggregation via a TXA2dependent mechanism. The detractive effect of losartan on TXA2-dependent platelet activation was independent from its effect on angiotensin II (25). Glycoprotein VI (GPVI) is an important receptor of collagen-induced platelet activation (26). Ono et al. (26) reported that losartan (DuP-753) inhibits platelet aggregation and adhesion by means of GPVI. EXP3179 is an active metabolite of losartan. EXP3179 functions as a specific inhibitor of GPVI independent of AT1receptor antagonism (27).

An in-vitro analysis has shown that losartan plus candesartan, compared to valsartan, resulted in a higher reduction in TXA2-analogue binding of platelets (28).

ARBs, including valsartan, irbesartan, olmesartan, and telmisartan significantly reduce serum levels of CRP. This effect is contradictory for losartan and candesartan (29). In our study, we did not observe changes in ESR and CRP values following treatment with losartan.

An intact and activated renin-angiotensin system (RAS) may be an important factor for erythropoiesis. Antihypertensive drug usage may be associated with a reduction in hemoglobin level. The mechanism of antihypertensive drug-related reduction in hemoglobin level include hemodilution, hemolytic anemia, and suppression of red blood cell production, as this occurs most commonly with angiotensinconverting enzyme inhibitors and ARBs. Indeed, a dose-dependent decrease in hematocrit level is observed in the first months of such therapy $(30,31)$.

In the current study, this hematological impression could be an additional benefit to antihypertensive effect via decreasing atherosclerotic process due to attenuated viscosity and inhibited platelet aggregation. The reduction in hemoglobin and hematocrit levels could be related to decrease in erythropoiesis via 
direct or indirect (with the antihypertensive effect) inhibition of erythropoietin. The hematological effects along with antihypertensive effect of losartan could be important. This situation does not seem to be a group effect.

\section{Conclusion}

Losartan may produce independent activities apart from its antihypertensive effects by providing significant reductions in platelet aggregation with ristocetin, hemoglobin and hematocrit levels. Thus it may be beneficial in the prevention of atherosclerosis and thrombosis.

\section{Study Limitations}

There are some limitations in this study. First, platelet aggregometry can evaluate platelet activity in hypertensive patients, but has some limitations. Standardization of this process is difficult (32). Repeatability of this process is important to avoid incorrect results (33). However, these tests were not repeated in our study. Second, the sample size in our study was relatively small. Third, we were not able to evaluate the effects separately in stage 1 and 2 hypertensive patients due to the limited number of subjects.

\section{Authorship Contributions}

Informed Consent: Consent form was filled out by all participants. Concept: Irfan Yavaşoğlu, Mustafa Ünübol, Design: Gürhan Kadıköylü, Irfan Yavaşoğlu, Mustafa Ünübol, Bilal Acar, Data Collection or Processing: Mustafa Ünübol, Bilal Acar, Analysis or Interpretation: Zahit Bolaman, Irfan Yavaşoğlu, Mustafa Ünübol, Bilal Acar, Literature Search: Irfan Yavaşoğlu, Mustafa Ünübol, Bilal Acar, Writing: Irfan Yavaşoğlu, Mustafa Ünübol, Peer-review: Extemal and internal peer-reviewed, Conflict of Interest: This study has not been published in any journal. We have not conflict of interest. Financial Disclosure: The authors declared that this study has received no financial support.

\section{References}

1. Wolf $M$, Heuten HG, De Swaef $A$, de Falleur $M$, Verpooten GA. The evolution of hypertension treatment in Belgium, a pharmacoepidemiological study. Acta Cardiol 2012; 67: 147-52.

2. Sato $Y$, Fujii $S$, Imagawa $S$, Ohmura $K$, Ohmura $Y$, Andoh $Y$, et al. Platelet aggregability in patients with hypertension treated with angiotensin II type 1 receptor blockers. J Atheroscler Thromb 2007; 14: 31-5.
3. Chrysant SG, Chrysant GS. The pleiotropic effects of angiotensin receptor blockers. J Clin Hypertens (Greenwich) 2006; 8: 261-8.

4. Andrioli G, Ortolani R, Fontana L, Gaino S, Bellavite P, Lechi C, et al. Study of platelet adhesion in patients with uncomplicated hypertension. J Hypertens 1996; 14: 1215-21.

5. Pathansali R, Smith NM, Bath PM. Prothrombotic megakaryocyte and platelet changes in hypertension are reversed following treatment: a pilot study. Platelets 2001; 12: 144-9.

6. Bavry AA, Li D, Zander DS, Phillips MI, Mehta JL. Inhibition of arterial thrombogenesis by quinapril but not losartan. J Cardiovasc Pharmacol Ther 2000; 5: 121-7.

7. Levy PJ, Yunis C, Owen J, Brosnihan KB, Smith R, Ferrario CM. Inhibition of platelet aggregability by losartan in essential hypertension. Am J Cardiol 2000; 86: 1188-1192.

8. Chobanian AV, Bakris GL, Black HR, Cushman WC, Green LA, Izzo $\mathrm{JL} J \mathrm{~J}$, et al; Joint National Committee on Prevention, Detection, Evaluation, and Treatment of High Blood Pressure. National Heart, Lung, and Blood Institute; National High Blood Pressure Education Program Coordinating Committee. Seventh report of the Joint National Committee on Prevention, Detection, Evaluation, and Treatment of High Blood Pressure. Hypertension 2003; 42: 1206-52.

9. Ozaki Y, Satoh K, Yatomi Y, Yamamoto T, Shirasawa Y, Kume S. Detection of platelet aggregates with a particle counting method using light scattering. Anal Biochem 1994; 218: 284-94.

10. Tohgi H, Takahashi H, Watanabe K, Kuki H, Shirasawa Y. Development of large platelet aggregates from small aggregates as determined by laser-light scattering: effects of aggregant concentration and antiplatelet medication. Thromb Haemost 1996; 75: 838-43.

11. Gimbrone MA Jr, Topper JN, Nagel T, Anderson KR, GarciaCardena G. Endothelial dysfunction, hemodynamic forces, and atherogenesis. Ann N Y Acad Sci 2000; 902: 230-9.

12. Özsavci $D$, Şener A, Oba R, Demirel GY, Uras F, Yardımcı TK. New in vitro effects of clopidogrel on platelets in hyperlipidemic and healthy subjects. Turk J Hematol 2010; 27: 99-108.

13. Monton M, Jimenez A, Nunez A, Lopez-Bloya A, Farre J, Gomez J, et al. Comparative effects of angiotensin II AT-1-type receptor antagonists in vitro on human platelet activation. J Cardiovasc Pharmacol 2000; 35: 906-13.

14. Lopez-Farre A, Sanchez de Miguel L, Monton M, Jimenez A, Lopez-Bloya A, Gomez J, et al. Angiotensin II AT(1) receptor antagonists and platelet activation. Nephrol Dial Transplant 2001; 16 Suppl 1: 45-9.

15. Jimenez AM, Monton M, Garcia R, Nuriez A, Gomez J, Rico L, García-Colis $E$, et al. Inhibition of platelet activation in strokeprone spontaneously hypertensive rats: comparison of losartan, candesartan, and valsartan. J Cardiovasc Pharmacol 2001; 37: 406-12.

16. Yamamoto K, Ozaki H, Takayasu K, Akehi N, Fukui S, Sakai A, et al. The effect of losartan and amlodipine on left ventricular diastolic function and atherosclerosis in Japanese patients with mild-to-moderate hypertension (J-ELAN) study. Hypertens Res 2011;34: 325-30. 
17. Chabielska E, Pawlak R, Buczko W. Losartan does not influence the blood platelet aggregation in normotensive rats. Acta Physiol Hung 1996; 84: 271-2.

18. Nossaman BD, Baber SR, Nazim MM, Detrolio JD, Kadowitz PJ. Differential effects of losartan and candesartan on vasoconstrictor responses in the rat. Can J Physiol Pharmacol 2007; 85: 360-71.

19. Nomura S, Shouzu A, Omoto S, Hishikawa M, Fukuhara S, Iwasaka T. Losartan and simvastatin inhibit platelet activation in hypertensive patients. J Thromb Thrombolysis 2004; 18: 177-85.

20. Akdemir R, Ozhan H, Yazici M, Gunudz H, Duran S, Gurel C, et al. In vivo effect of losartan on platelet aggregation in patients with hypertension. Heart Vessels 2004; 19: 167-71.

21. Yamada K, Hirayama T, Hasegawa Y. Antiplatelet effect of losartan and telmisartan in patients with ischemic stroke. J Stroke Cerebrovasc Dis 2007; 16: 225-31.

22. Devereux RB, Dahlöf B. Potential mechanisms of stroke benefit favoring losartan in the Losartan Intervention For Endpoint reduction in hypertension (LIFE) study. Curr Med Res Opin 2007; 23: 443-57.

23. Schwemmer $\mathrm{M}$, Sommer $\mathrm{O}$, Bassenge E. Angiotensin receptor blocker losartan suppresses platelet activity by interfering with thromboxane signaling. Cardiovasc Drugs Ther 2001; 15: 301-7.

24. Jagroop IA, Mikhailidis DP. Angiotensin II can induce and potentiate shape change in human platelets: effect of losartan. J Hum Hypertens 2000; 14: 581-5.

25. Guerra-Cuesta JI, Monton M, Rodriguez-Feo JA, Jimenez AM, Gonzalez-Fernandez F, Rico LA, et al. Effect of losartan on human platelet activation. J Hypertens 1999; 17: 447-52.
26. Ono K, Ueda H, Yoshizawa Y, Akazawa D, Tanimura R, Shimada I, et al. Structural Basis for Platelet Antiaggregation by Angiotensin II Type 1 Receptor Antagonist Losartan (DuP-753) via Glycoprotein VI. J Med Chem 2010; 53: 2087-93.

27. Grothusen C, Umbreen S, Konrad I, Stellos K, Schulz C, Schmidt $B$, et al. EXP3179 inhibits collagen-dependent platelet activation via glycoprotein receptor-VI independent of AT1-receptor antagonism: potential impact on atherothrombosis. Arterioscler Thromb Vasc Biol 2007; 27: 1184-90.

28. Nunez A, Gomez J, Zalba LR, Monton M, Jimenez A, Velasco S, et al. Losartan inhibits in vitro platelet activation: comparison with candesartan and valsartan. J Renin Angiotensin Aldosterone Syst 2000; 1: 175-9.

29. Prasad K. C-reactive protein (CRP)-lowering agents. Cardiovasc Drug Rev 2006; 24: 33-50.

30. Marathias KP, Agroyannis B, Mavromoustakos T, Matsoukas J, Vlahakos DV. Hematocrit-lowering effect following inactivation of renin-angiotensin system with angiotensin converting enzyme inhibitors and angiotensin receptor blockers. Curr Top Med Chem 2004; 4: 483-6.

31. Sica DA, Mannino R. Antihypertensive medications and anemia. J Clin Hypertens (Greenwich) 2007; 9: 723-7.

32. Breddin HK. Can platelet aggregometry be standardized? Platelets 2005; 16: 151-8.

33. Ghosh K, Nair S, Kulkarni B, Khare A, Shetty S, Mohanty D. Platelet function tests using platelet aggregometry: need for repetition of the test for diagnosis of defective platelet function. Platelets 2003; 14: 351-4. 